\title{
Quality of Hemoglobin and Nutritional Status on Children Aged 6-24 Months
}

\author{
$1^{\text {st }}$ Arlyana Hikmanti \\ D3 Midwifery Study Program,Faculty of Health \\ Harapan Bangsa University \\ arlyanahikmanti@uhb
}

\author{
$2^{\text {nd }}$ Fauziah Hanum Nur Adriyani \\ D3 Midwifery Study Program,Faculty of Health \\ Harapan Bangsa University \\ fauziahhanum@uhb.ac.id
}

\begin{abstract}
Age below five, especially 624 months is a transition age that is vulnerable to malnutrition. Children who experience malnutrition will experience growth and development disorders, iron deficiency anemia. The purpose of this study was to determine the correlation between hemoglobin status and nutritional status on children aged 6-24 months. The research method is quantitative research with cross sectional approach. The samples were all children aged 6-24 months comprising of 132 children. The data was analyzed using the fisher exact with a significance level of $95 \%$ $(\alpha$

$<0.05)$. The results showed that the value of $\alpha=0.435>0.05$. Conclusions: there is no correlation between hemoglobin levels and nutritional status in children aged 6-24 months.
\end{abstract}

\section{nutritional status}

Keywords: hemoglobin,

\section{INTRODUCTION}

Malnutrition contributes 3.1 million children's deaths out of $45 \%$ of all causes of death. WHO estimates that 2 out of 5 children experience developmental delay (stunting and wasting). This will increase the risk of death in children [1]. Giving breastfeeding recommended by WHO is exclusive breastfeeding until the age of 6 months, then it is continued with weaning.
The transition after exclusive breastfeeding to weaning is a transition period that is vulnerable to the malnutrition occurrence in infants that contributes significantly to the prevalence of malnutrition, stunting under five years old and developmental disorders [2]. Nutrient deficiency is common in developing countries, including Indonesia. Malnutrition can cause Iron Deficiency Anaemia (ADB) which has an impact on children's growth and development.[3] The results of a study indicate that toddlers with stunting have $33 \%$ lower haemoglobin levels compared to those who are not stunting. [4] In

Indonesia the incidence of stunting reaches $28 \%$ of the total children under two.(Kemenkes, 2018) Nutritional status is a parameter of children's health. Indonesian government launched a health development program in the period of 2018-2019. One of the goals is a decrease on the prevalence of stunting and non-communicable diseases especially on toddlers by monitoring the nutritional status regularly as a parameter of the health on toddlers. [6] Anaemia is low haemoglobin levels which can reduce oxygen delivery in body tissues. The most vulnerable population is preschool children by $47 \%$. The main cause of anaemia in children is micronutrient deficiency, especially iron, which results in chronic diseases. This chronic diseases mostly lead to stunting.[7] Stunting is a disorder of linear growth and inadequate 
food intake.[8] In developing countries, stunting contributes one-third of development disorders on children under five years old because the maximal development of a child's lobe starts at 6 months old and continues until adulthood. [9] To overcome this, children under five who are suffering from stunting are given biscuits that have been formulated and fortified to fulfil the needs of malnourished children. Among them contain iron, that is expected to increase the nutritional adequacy rate of children. Every $1 \mathrm{gr} / \mathrm{dl}$ can reduce the risk of death $24 \%$, this substance can be found in the biscuits provided.[10]

\section{MATERIAL AND METHOD}

This study was an observational analytic study with cross-sectional design. The population of this study was 132 children aged 6-24 months in Karangklesem Village, South Purwokerto. Samples were taken by a total sampling consisting of 132 children aged 6-24 months. Exclusion Criteria 1) Children aged 6-24 months who suffer from continental disability. The dependent variable is the nutritional status with the status of breastfeeding and weaning with formula milk and weaning is done at the age of 6-24 months. Data collection was performed using primary data to determine height, weight and haemoglobin levels of children. The independent variable was the haemoglobin level of children aged 6-24 months. The data obtained were processed by computerization, and analysed using fisher exact and bed test with a significance level of $\mathrm{p}<0.05$.

\section{FINDINGS AND DISCUSSION}

Table 1.1 shows that based on statistics there is no correlation between hemoglobin status and nutritional status of children aged $6-24$ months $(\alpha=0.435>0.05)$. The results of this study are not in line with the results of the study which showed that there was a positive correlation between hemoglobin levels and nutritional status in children [11].
Table 1 Correlation between hemoglobin

levels and nutritional status of children aged 6-24 months

\begin{tabular}{|c|c|c|c|c|c|c|c|c|}
\hline \multirow[b]{2}{*}{$\begin{array}{l}\text { Haemo } \\
\text { globin } \\
\text { status }\end{array}$} & \multicolumn{6}{|c|}{ Nutritional status } & \multirow[b]{2}{*}{ Total } & \multirow{2}{*}{$\begin{array}{c}\text { Nilai } \\
\mathrm{p}^{*}\end{array}$} \\
\hline & $\begin{array}{l}\text { Nor } \\
\text { mal }\end{array}$ & $\mathrm{f}(\%)$ & $\begin{array}{l}\text { Stunt } \\
\text { ing }\end{array}$ & $\begin{array}{c}\mathrm{f} \\
(\% \\
)\end{array}$ & $\begin{array}{c}\text { Very } \\
\text { stunt } \\
\text { ing }\end{array}$ & $\begin{array}{c}\mathrm{f} \\
(\% \\
)\end{array}$ & & \\
\hline $\begin{array}{l}\text { Anemi } \\
\text { a }\end{array}$ & 28 & 21,2 & 14 & $\begin{array}{l}10, \\
6\end{array}$ & 5 & 3,8 & 47 & $\begin{array}{l}0, \\
435\end{array}$ \\
\hline $\begin{array}{l}\text { Tidak } \\
\text { anemi } \\
\text { a }\end{array}$ & 42 & 31,8 & 28 & $\begin{array}{l}21, \\
2\end{array}$ & 15 & $\begin{array}{l}11, \\
4\end{array}$ & 85 & \\
\hline Total & & & & & & & 132 & \\
\hline
\end{tabular}

*) fisher exact

This is reinforced by the results of a study that children who are not anemic will have a

good nutritional status because hemoglobin levels within normal limits will have good appetite characteristics. [12]. This is possible because children aged 6-24 months who experience stunting have been given supplements to improve their nutritional status from Community Health Service, so that hemoglobin levels in stunting children do not experience anemia. This is in accordance with the government objectives where handling and preventing nutritional problems on children under five is carried out by giving supplementary snack in the form of toddler biscuits [13]

Supplementary snack for toddler is a biscuit which is specially formulated and fortified containing minerals (iron, iodine, zinc, calcium, and phosphor) and vitamins (A, D, E, K, B1, B2, B3, B12, Folate ) to meet nutritional needs. [14] Based on the results of a research in

Semarang, supplements containi vitamins and minerals can significantly increase appetite and nutritional status of children by 4.1 to 5 times per day when combined with zinc. [12] This supplementation will increase more significant result if given for more than 4-6 months, and iron is recommended to be given to children who have iron deficiency risk such as babies who get low iron formula milk birth history of mothers anemia during pregnancy.[3] ) $h$ results in Sri Lanka show that with stunting has. The supplement and calcium helps children in 
their bone growth, helps in weight through

thermogenesis, as well as helps fat

oxidation and controlling full feeling.[11]

The result of a study also showed that toddlers who have no anemia can have normal nutritional status or stunting. It is not in line with research conducted by Longsong et. al who stated that toddlers having anemia tend to experience stunting as much as $33.33 \%$.[4] Anemia and stunting in children can occur together because it is very likely that children experience complex nutritional problems at 6- 24 month age. Based on the result of a research conducted in Nepal indicated that at the age of 6-23 months there is a condition of food insecurity where parents' job takes into consideration the adequacy of children's nutritional fulfillment. [15] The weaknesses of this study is that it was done using cross sectional so it cannot be recognized the causes and effects.

\section{IMPLICATIONS FOR PRACTICE}

The finding of this study is very important because it is beneficial to review the use of existing interventions in children with stunting as an effort to improve their nutritional status. Of course, this is inseparable from the commitment and role of the Community Health Center in organizing the stunting prevention intervention program.

\section{Conclusion}

There is no correlation between hemoglobin level and nutritional status in children aged 6-24 months. Hence, children who experience growth disorders in this period should continue the feeding and also consuming supplement food as recommended.

\section{StRENGTH AND LimitATION}

This research has strengths and limitations. The strength of thi finding is that it is observational in direct measurement in infants. This systematic review has strengths and limitations. The limitation of this study is that researchers only observed the nutritional status and hemoglobin levels of children at this time, so it is quite difficult to distinguish the effects of interventions given to infants with stunting.

\section{BIBLIOGRAPHY}

[1] W. Fentahun, M. Wubshet, and A. Tariku, "Undernutrition and associated factors among children aged 6-59 months in East Belesa District, northwest Ethiopia: A community based cross-sectional study," BMC Public Health, vol. 16, no. 1, pp. 1-10, 2016.

[2] World Health Organisation., "WHO | Complementary feeding," World Health organisation. 2016.

[3] D. Gunadi, B. Lubis, and N. Rosdiana, "Terapi dan Suplementasi Besi pada Anak," Sari Pediatr., 2016.

[4] N. H. F. Losong and M. Adriani, "Perbedaan Kadar Hemoglobin, Asupan Zat Besi , dan Zinc pada Balita Stunting dan Non Stunting The Differences of Hemoglobin Level, Iron , and Zinc Intake in Stunting and non Stunting Toodler," Amerta Nutr., vol. 1, no. 2, pp. 117-123, 2017.

[5] Kemenkes, "Hasil Utama Riskesdas Tentang Prevalensi Diabetes Mellitus di Indonesia 2018," Has. Utama Riskesdas Tentang Prevalensi Diabetes Melitus di Indones. 2018, p. 8, 2018.

[6] Kemenkes, "InfoDatin:Situasi Balita Pendek," 2016.

[7] S. Syed, O. Y. Addo, V. De La Cruz-Góngora, F. A. S. Ashour, T. R. Ziegler, and P. S. Suchdev, "Determinants of anemia among school-aged children in Mexico, the United States and Colombia," Nutrients, vol. 8, no. 7, pp. 1-15, 2016.

[8] E. K. M. Darteh, E. Acquah, and A. Kumi-Kyereme, "Correlates of stunting among children in Ghana," BMC Public Health, vol. 14, no. 1, 2014.

[9] M. Perignon et al., "Stunting, poor iron status and parasite infection are significant risk factors for lower cognitive performance in 
Cambodian school-aged children," PLoS One, vol. 9, no. 11, 2014.

[10] S. P. Scott, L. P. Chen-Edinboro, L. E. Caulfield, and L. E. MurrayKolb, "The impact of anemia on child mortality: An updated review," Nutrients, vol. 6, no. 12, pp. 5915-5932, 2014.

[11] E. Marasinghe, S. Chackrewarthy, C. Abeysena, and S. Rajindrajith, "Micronutrient status and its relationship with nutritional status in preschool children in urban Sri Lanka," Asia Pac. J. Clin. Nutr., vol. 24, no. 1, pp. 144-151, 2015.

[12] A. Candra, "Pengaruh Suplementasi Seng dan Zat Besi Terhadap Berat Badan dan Tinggi Badan Balita," JNH (Journal Nutr. Heal., vol. 5, no. 1, pp. 37-44, Mar. 2017.

[13] Kementerian Kesehatan RI, "Pusdatin: buletin stunting," Kementeri. Kesehat. RI, vol. 1, p. 2, 2018.

[14] Kementerian Kesehatan RI, "Petunjuk Teknis PMT," Petunjuk Tek. PMT, 2017.

[15] A. Osei et al., "Household Food Insecurity and Nutritional Status of Children Aged 6 to 23 Months in Kailali District of Nepal," Food Nutr. Bull., vol. 31, no. 4, pp. 483494, 2015. 